\title{
Impact of Youtube and Video Podcast on Listening Comprehension Among Young Learners
}

\author{
https://doi.org/10.3991/ijim.v15i20.23701 \\ Aizan Yaacob ${ }^{1(\mathbb{凶})}$, Amira Shazmin Amir Amir ${ }^{1}$, Ratnawati Mohd Asraf ${ }^{2}$, \\ Mohd Faiz Mohd Yaakob ${ }^{1}$, Farah Mohamad Zain ${ }^{1}$ \\ ${ }^{1}$ Universiti Utara Malaysia, Kedah, Malaysia \\ ${ }^{2}$ International Islamic University Malaysia, Selangor, Malaysia \\ aizan904@uum.edu.my
}

\begin{abstract}
Even though listening comprehension is an important language skill in second language learning, it is considered to be the most difficult skill to learn. Besides, the teaching of listening comprehension among primary pupils is often neglected even though the role of listening comprehension in language teaching has been repeatedly emphasized. Using an action research design, this study explores the teaching of listening comprehension utilizing YouTube and Video-Podcast involving 40 Primary Year 4 pupils from one of the cluster schools of excellence in the northern region of Malaysia. This study attempts to investigate to what extent did the use of YouTube and Video-Podcast enhance Primary Year 4 pupils' listening comprehension. This study adopted multiple data collection methods including pre-post tests, reflection, observation, and focused group interviews. However, the data analysis section was mostly pre and post tests data and observation. Only these data collection and analysis tools will be expanded in this study, and not the reflection and focus group interviews. The quantitative data were analyzed statistically using paired sample t-test while thematic analysis was used for analyzing the qualitative data. The findings revealed that YouTube and Video-Podcast yielded positive significant impact on listening comprehension skills among Primary ESL pupils. There was statistically significant increase in listening comprehension scores from pre-test and post-test. Four themes emerged from the observation data. It increased learners' participation and understanding, developed team spirit as well as enhanced interest and motivation of the young learners.
\end{abstract}

Keywords - YouTube educational channel, video-podcast, listening comprehension, ELT, rural ESL

\section{$1 \quad$ Introduction}

Listening is seen as one of the toughest skills to learn [1]. Earlier studies have indicated that listening anxiety and lack of vocabulary are among the major issues in ESL young learners' listening comprehension skill [2]. As such, it often causes high listening anxiety resulting in poor listening achievement [3]. Slang, fast speaking pace, and lack 
of repetition are some of the causes of high listening anxiety and difficulties in understanding the language learned [4]; [5]; [6]. Other challenges in listening comprehension among the primary ESL young learners are: lack of vocabulary, topics that are not common to their daily practices, fast speech rate, and accent [5]. Insufficient vocabulary can cause difficulties in understanding the content of the language, while in terms of accent, pupils can comprehend better when they hear their local accent compared to the native speakers' accent [6].

The tech-savvy millennials are known for their efficiency in using the social media such as YouTube, Facebook, Twitter, Video-Podcast, and Instagram. YouTube is an online website which is popular among all walks of life because it provides many authentic materials for free [7]. It becomes more popular especially among young learners and adults due to its user-friendliness, whereby they can access videos on YouTube anywhere and anytime through their computers and smartphones [8]; [9]; [10]; [11]. The authentic materials such as videos uploaded in the educational channel may help the young learners to improve their listening skills [12]. This is due to the fact that most of the contents in the videos uploaded in the education channel are selected carefully to ensure its content appropriateness for education and learning [13]. For example, the channel from the British Council English Learn for Kids can connect the ESL young learners to their learning environment, while the available audiovisual aids can assist them in retaining the input easily to capture their attention [14]. This channel does not only provide meaningful and interesting learning environment but also creates enjoyment in exploring new tools for learning [15]

Video-Podcast is another Web 2.0 tool that helps young learners to enhance their English listening comprehension skills and reduce listening anxiety because it provides a classroom environment through its educational content [16]. [17] revealed the advantage of Video-Podcast as a study-like environment that helps teachers to use it as an additional teaching materials and at the same time, improves pupils' engagement. Besides, it is an up-to-date source of audio and video materials that can help them to learn beyond the classroom walls [18]. Ultimately, it will help them to improve their listening comprehension skills through fun and engaging activities using authentic learning materials [19];[20]. However, listening instruction, particularly in the ESL context is often neglected and less attention is given to teaching listening during the learning process because it is assumed that listening can easily be acquired through daily conversation and practices. In Malaysia particularly, listening is not tested in the examination. Therefore, teachers tend to pay more attention to reading and writing, and less emphasis is given to listening. Besides, the use of technology in teaching English is still low [21] [22]. Taking into consideration the challenges in acquiring listening comprehension skills among ESL learners and acknowledging the benefits of social media on students' language learning, this paper reports the findings of the study that investigated the impact of YouTube and Video-Podcast in enhancing Primary Year 4 pupils' listening comprehension skills.

\section{Literature review}

Listening comprehension is one of the most important elements in English language learning and it is described as an active process that involves the learners to 
form meaning from the spoken language [23]. It is also explained as the process of understanding the language spoken, grammatical structures, and the ability to differentiate sounds of the language which can help develop good listening comprehension skill [24]. Listening comprehension is also defined as the content that the listeners understand from hearing the spoken language [25]. There are five major challenges in listening comprehension namely: Listeners are not in control of the speaker and the speech rate, the words are not repeated unless the teacher repeats the audio, lack in vocabulary such as unfamiliar words which can cause difficulties for the learners to comprehend the listening input, lack of ability in visualizing unless teachers provide them with video or visual input, and finally, dreary listening materials which may lead to lack of responsiveness in listening.

Therefore, to make the session more alive and engaging, a variety of activities need to be provided so that the pupils will have the opportunity to explore and learn the language. As such, teachers need to provide the pupils with ample wait time so that they will have enough time to answer the given questions. Apart from that, another problem that contributes to challenges in listening comprehension skills among ESL learners is that the teacher demands for the correct and complete answer with only a little time provided to them. Consequently, this will cause the young learners to have less interest to listen and learn [26].

Moreover, ESL teachers need to plan well on the selection of the materials so as to ensure that the learning outcomes of the lesson can be achieved [27]. Proper selection of listening comprehension material should be done thoroughly to counteract the unsuitability of the listening materials [28]. Besides, it will also warrant more comprehensible input and interactive listening lesson [29]. One way to sustain learners' interest in listening is by integrating technology in teaching and learning.

\subsection{YouTube and Video Podcast}

There is a growing body of literature that recognizes the benefits of technology in teaching and learning [21]; [22]; [8]; [9]; [10]; [30]; [31]. YouTube is one of the technological tools that contains the elements of audio and visual learning environment [32]. It is user friendly, free, suitable for young learners and often used in language learning because it can disseminate knowledge in a fun and engaging way. It is also known as one of the most successful interactive audio-visual websites because the fun and engaging element in the channel helps to develop meaningful learning interaction [33]. It also helps to support the blended learning pedagogy approach to promote language learning among the pupils [34]; [35]. The concept of global language learning provided in the YouTube educational channel provides many authentic teaching materials such as videos, online notes, and presentations from pupils around the world [36]. It proposes easy access to language learning videos and instruction from all around the world [37].

YouTube educational channel can fulfill the language learning process since it contains fun elements that help to reduce anxiety and boredom [38]. The fun elements allow them not only to enjoy the lesson better, but also permits them to become the content creators of their learning materials [39]. In other words, through this channel, learners learn to record their presentations of the topic taught through the use of a webcam. They can also upload their videos and presentations on the YouTube educational 
channel as the learning materials that can be accessed and viewed by subscribers around the world. The content of the lesson can support pupils' learning to be more interactive and engaging [40].

It has become part of the most popular mobile learning application which consists of not only portable audio but also video players. Video-Podcast is an educational digital content which is accessible through iPod and broadcasting through the internet [41]. It is also well known for its authentic materials which help in language teaching and learning. It has been revealed that the use of Video-Podcast in language learning helps to improve the pupils' engagement as their learning becomes a lot more fun [42]. Video-Podcast has replaced disc, DVD, and radio cassette. It is free and downloadable. It can be accessed through laptops and smartphones. The use of Video-Podcast has become an important part of language learning and teaching as it provides authentic teaching and learning materials [43]. The integration of Video-Podcast has given great effects in the life of the pupils as they enjoy. This is supported by those who revealed that the use of Video-Podcast in language learning can bring in the real atmosphere into the classroom and can expose the pupils to the target language and culture [44]. Language learning through Video-Podcast also enables pupils to feel free and relaxed whereby they can enjoy listening and watching the Video-Podcast at their own pace and during their free time. In another study, learners progress in the second language learning through the exposure of audio, interactive videos and appropriate level of texts in the Video-Podcast [45]. This study was underpinned by the Social Constructivism Theory by Vygotsky. Social Constructivism theory emphasizes on collaborative learning with peers. [46] believed that knowledge is co-constructed between two or more adults and that the zone of proximal development (ZPD) differentiates what the learners can do alone and what they can learn with assistance from more knowledgeable others. In the context of this study, students became active learners as they engaged in the learning using YouTube and Video-Podcast, and at the same time, they worked collaboratively with their peers to solve the listening tasks.

\section{$3 \quad$ Methodology}

\subsection{Research design}

This study adopted an action research design which aimed at improving teaching practice. Action research is suitable for educational research because it involves gathering information that is in line with the current education programs and issues, analyzing the information, developing an intervention to cater to the problems, collecting changes after re-planning if necessary and developing conclusions about the findings. In the context of this study, the data were collected in three phases whereby the data were accumulated through a series of plan, act, observe, and reflect cycles. The participants of this study were selected through convenient sampling. The participants of this study were 40 Primary Year 4 learners from a primary cluster school of excellence located in the northern region of Malaysia. The participants consisted of 21 male and 19 female students aged 10 years old. They were from an intact classroom of mixed abilities with high, average, and low proficiency in the English Language. The students were allowed 
to choose their own group members, known as "friendship group". "Friendship groups can exhibit disclosure and open discussion, especially if people feel more vulnerable." [47, p. 114]. They were organized in two groups: all male and all female due to religious and cultural preferences. This was also intended to enhance their mutual understanding to develop great teamwork when completing the task. One of the researchers is the participant in this action research. Multiple methods such as Pre-test, Post-test, semi-structured interview, and observation were used in this study. The Pre-test and Post-test were adopted from the British Council English Learn Kids Channel on YouTube. The tests consisted of 12 picture-word matching questions, story sequencing, True/False statements and open ended questions. The pre-test and post-test questions were given to two expert panels who are the Head of the English Panel for validation. The time allotted for the test was 40 minutes.

A set of semi-structured interview protocol was adapted from [48] and [49]. The interviews were conducted in both Bahasa Malaysia (L1) and English, using two focused groups based on the learners' preference. Observations were conducted twice: pre-observation during the problem identification stage, and post-observation during the intervention and evaluation stages. The observations were conducted to allow the researchers to see the patterns of interaction during listening activities. All the observation data were recorded, transcribed and analyzed.

\subsection{Data collection procedures}

This action research involved three phases: Problem identification, intervention and evaluation, which was conducted within 8-weeks period. During the Problem Identification Phase (which involved 2 lessons), the pupils listened to audio only, which was the traditional way of teaching listening in ESL classroom. The purpose of the problem identification stage was to identify problems related to low listening comprehension ability among the pupils. At this stage, the teacher played the audio twice. The teacher did not display any pictures, videos, or subtitles to help the pupils answer the questions given. The audio was based on the short stories such as Robin Hood and The Magic Paint Brush. The pupils had no prior knowledge of the story and they were not told what to listen to. After listening to the first short story, Robin Hood, the teacher distributed the pre-test questions to the pupils. The pre-test questions consisted of different activities which were picture-vocabulary matching, story sequencing, true and false, and open-ended questions. The pupils were required to answer the questions given. In the following lesson, the teacher did a similar activity using another story, The Magic Paintbrush.

In Phase 2, which was the intervention stage, the pupils were introduced to stories using YouTube and video podcast. This intervention lasted for 4 weeks and involved 4 stories which were 'The Sneaky rabbit, The clever monkey, Why Anansi Has Thin Legs, and Dick Whittington. The purpose of the intervention stage was to examine the extent of Youtube and video podcast on students' listening comprehension. During this phase, the pupils were allowed to choose their group members and to work collaboratively in their respective groups. During lesson 1, about The Clever Monkey, the video with subtitles was played twice. The pupils collaborated with their group members to 
answer the listening tasks. The pre-group observation was conducted to see the pattern of how the pupils collaborated to answer listening comprehension questions. The intervention phase was also conducted to enhance better listening comprehension skills among the Primary Year 4 pupils. The pupils were given a variety of activities such as creating a big book by sequencing the story and images, making a sentence scroll to see the flow of the story, and re-arranging the letters to form words. Post observations and focused group interviews were recorded and transcribed.

During Phase 3, which was the evaluation stage, the pupils' listening comprehension scores were assessed through a set of post-test questions. The pupils were tested based on the content of the stories, 'The Little Red Riding Hood' and 'Jack and the Beanstalk'. Focus group interviews were also conducted with the students at this stage.

\subsection{Data analysis}

Data in this paper included mostly pre and post — tests data with observation. All the findings from the pre and post-tests were analyzed using paired sample t-test while the qualitative data were analyzed using thematic analysis [47]. The qualitative analysis involved transcribing, reading and familiarizing, coding, searching for themes, reviewing themes, defining and naming themes, and finally finalizing and writing the analysis.

\subsection{Validity and reliability}

In ensuring validity and reliability of the study, the qualitative data were given to two English teachers known as 'expert teachers' in the school for 'member checking'. This acts as a 'credibility check' to ensure that "there is a good fit between their intrepretations and representations of their participants' experiences..." [47 p.282]. Besides 'member checking', methodological triangulation was also used to ensure trustworthiness of the study. With regard to the ethical issues, this study adhered to ethical requirements needed in any research. Firstly, a letter of request for approval was submitted to the Economic Planning Unit (EPRD), the Ministry of Education, Malaysia, prior to conducting this study. Secondly, after receiving the approval, informed consent was obtained from the participants and they were informed of their right to withdraw from the research during or after it has taken place. Next, pseudonyms were placed to all the students' names to protect their anonymity and confidentiality.

\section{$4 \quad$ Findings}

The study was conducted to determine how YouTube and Video-Podcast have impacted the listening comprehension skills of the Primary Year 4 pupils. In this paper only the data from the pre and post - tests, and the observation were analyzed and presented to answer the research question. 


\subsection{Quantitative analysis}

The purpose of conducting the pre- and post-tests was to examine the impact of Youtube and Video podcast on students' listening comprehension.

Table 1. Results of the effectiveness of Youtube and Video podcast on listening comprehension

\begin{tabular}{|l|c|c|c|c|c|c|}
\hline \multicolumn{1}{|c|}{ Test } & N & Mean & SD & Df & t & p \\
\hline Pre Test & 40 & 46.03 & 9.39 & 39 & -25.33 & 0.00 \\
\hline Post Test & 40 & 80.58 & 8.86 & - & - & - \\
\hline p value & & & & & & $<0.05$ \\
\hline
\end{tabular}

As indicated in Table 1, there was statistically significant increase in listening comprehension scores from pre-test $(\mathrm{M}=46.02, \mathrm{SD}=9.39)$ and post-test $[\mathrm{M}=80.57$, $\mathrm{SD}=8.86, \mathrm{t}(39)=-25.33, \mathrm{p}=0.000 ; \mathrm{p} \leq 0.05]$. The findings indicate that YouTube and video-podcast have impacted the listening comprehension performance. In other words, the students' listening comprehension increased when using YouTube and video-podcast.

\subsection{Qualitative analysis}

The qualitative data were obtained from observation and focus group interviews. As this is part of a bigger study, the data gathered from classroom observation were used in this paper to support the findings from the quantitative analysis. Four themes emerged from the observation data: Youtube and video podcast increased learners' participation and understanding, increased team spirit as well as developed interest and motivation. The following extracts illustrate the observation data obtained from two groups of students (the boy's and the girl's group) before they were introduced to the Youtube using the traditional teaching (pre-observation) and after been introduced to the Youtube (post observation).

\subsection{Pre observation}

In listing out all the characters mentioned in the story, the students did not have good interaction among their group members because most of them had no idea who the characters mentioned in the story were. This can be seen when S1 repeated what the teacher said (line 5). He wanted to know the answer by asking his other group members.

$$
\text { “<What are the characters?>” (S1, pre-observation) }
$$

S1 was unsure of the characters mentioned in the story. Unfortunately, S2 and S3 were also unable to list down the characters. They looked confused and started to comment on how the narrator narrated the story. S2 mentioned,

"<how do I know... the native speaker speaks too fast>” (S2, pre-observation) $<$ I also don 't understand the story. $>$ (S3, pre-observation) 
Frustration was evident in the conversations above. S2 complained that the narrator, in this case the native speaker or known as 'orang putih' <native speaker> spoke too fast and he could not catch up with his pace. Similarly, S3 also mentioned that he could not understand the whole listening text either. However, only S4 managed to understand the text and was able to list down the characters of the story. This is evident when he rephrased the words in the mother tongue (Bahasa Malaysia).

$$
\text { "<All I know is that the rabbit is smart.>” (S4, pre-observation) }
$$

On the other hand, S5 mentioned another character found in the story line but the answer was wrong.

$$
\text { “ }<\text { I heard there was a lion just now. }>\text { " (S5, pre-observation) }
$$

S5 had mistakenly given a wrong answer whereby it was actually a tiger, not a lion. Overall, the pre-observation data indicate that the pupils were not showing their active participation in the listening text due to the lack of understanding of the listening text and little help was offered among their group members. They could not identify the characters and the plot of the story due to the fast speed and pace of speaking of the native speaker. It can be seen that most of the pupils in this group were struggling to finish the task, and, they still could not get the right answer.

However, in the post observation, the interaction patterns improved where they managed to complete the task given by the teacher. The following excerpt shows the patterns of the pupils' participation after YouTube and video podcast were used as an intervention. During the lesson, the pupils were required to watch a video of a short story entitled, 'Dick Whittington' with English subtitles displayed on the video. They were required to complete the task by listing down the characters mentioned in the story.

\subsection{Post observation}

The post-observation, revealed that the students have improved in their interaction patterns. They were able to strategize their learning by assigning each member to list down only one character each. This strategy has helped them to complete the task. This is evident when S3 was able to lead the group by helping to delegate the task accordingly.

$$
\begin{gathered}
\text { "<Yes if that's the case... let us list down one character each. } \\
\text { Just jot down which one you can manage }>\text { " (S3, post-observation) }
\end{gathered}
$$

By doing so, his group members were able to list down all the characters mentioned in the story. S4 was able to name the main character of the story which is Dick Whittington, meanwhile, S5 and S6 were able to rephrase the storyline in their mother tongue (Bahasa Malaysia) and also to identify the other characters such as, the "rich businessman" and "the cat". Surprisingly, S1 and S2 were able to describe the characteristics of "the servants" and 'the daughter' who then became Dick Whittington's wife. 
This indicated that all the students in this group were able to comprehend the listening text after YouTube and video podcast were introduced to them.

When asked by the teacher, S1 explained that the task was not that difficult when they started to help each other by dividing the listening task into a more manageable one.

$<$ Not that difficult... we list down one character each that we heard...not difficult... then we combine what we wrote teacher $>$ " (S1, post-observation)

In summary, the boys' group managed to improve their listening task with the help of the Youtube Video with subtitles, shown to them. They divided the listening task among their group members and turned them into a more manageable one. Eventually, the task became easier as they discussed the characters with their group members.

In another classroom observation, the Girl's Group were recorded examining the story of 'Robin Hood'. In this lesson, the students were asked to find the sequence the story. During the pre-observation, there was no video or subtitles shown to the students. This lesson was conducted using audio-only (traditional way). The audio was played twice to help the pupils familiarize themselves with the storyline as well as to enhance their understanding of the story. The following extract shows the pre-observation data.

\subsection{Pre observation}

From the pre-observation data of the girl's group, it can be seen that most of the students in the group faced difficulties in sequencing the story due to the lack of understanding and familiarity of the story, for example, they did not know where to start because they did not understand the story. S1 asked while S2 supported her by admitting that she could not understand the story because she has never heard it before.

$$
\begin{aligned}
& \qquad<\text { Okay, where do we start? }>\text { " (S1, pre-observation) } \\
& \text { "<I do not understand the story. I have never heard of it before. }>\text { "(S2, pre) }
\end{aligned}
$$

This indicated that they could not remember the story line even from the beginning. However, S3 seemed to have some idea regarding the first sentence of the story line. She was able to rephrase the sentence using the mother tongue (Bahasa Malaysia).

“ $<$ I think the story starts with 700 years ago...after that I don't know >” (S3, pre)

From this excerpt, it can be seen that S3 showed little understanding of the text. As such, she was unable to help her group members to sequence all the sentences to form a meaningful story. On the other hand, S4 decided to guess the answer without even trying to recall what she heard from the audio. In the following lines 25 and 26, S5 and S6 tried to sequence the sentences to form a meaningful story. This was seen through their discussion.

$<$ Okay, I think number 2 is about a skillful archer.> (S5, pre-observation) $<$ No. I think number 2 lives in the forest $>$ (S6, pre-observation) 
Even though it is noticeable that they were confused about the correct sequence of the story, they still tried their best to complete the task. However, S1 was seen to be demotivated because she could not answer any of the questions given. She said she would rather guess the sequence of the story as long as she could finish the task given. This is evident when she said,

$<$ Let us just put the number. I really don't understand the story. $>(S 1$, pre)

In addition, she added that she did not understand the whole story at all. Similarly, S2 agreed with her suggestion to guess the answer.

$<$ okay, just fill in the number... then we can ask the teacher to check for us> (S2, pre)

From the excerpt above, it indicates that the students gave up on trying to sequence the sentences to form a meaningful story due to the lack of understanding and familiarity of the text. They ended up guessing the answers to complete the listening task. However, the situation improved with the help of Youtube and Video podcast. The following excerpt illustrates what happened during the post observation where they had to sequence the storyline.

\subsection{Post observation}

Post observation was conducted in order to see the pattern of students' understanding of the listening text when the intervention was conducted. Based on the excerpt above, it is noticeable that all the students were able to sequence the sentences to form a meaningful story. They have shown a better understanding of the story compared to the pre-observation lesson. Not only they managed to recall all the characters in the story, they were also able to describe the story well. During the pre-observation, S4 preferred to guess the answer instead of recalling the gist of the story. However, it is evident in the post observation that she had improved a lot in understanding the listening text. She knew the beginning of the story as she explained in line 20,

$<$ Dick started a very successful business of his own. Okay $><$ This is number 8.> (S4)

From the excerpt above, it is noticeable that S4 had mastered the strategy of sequencing the story line. Similarly, S3 was also able to sequence the story by choosing the beginning of the story. She explained to her friends about Dick Whittington who ran away to London. She said,

$<$ Now let us find the first (event)... the first one is about

Dick Whittington went to London... he ran away from his village.> (S3, post)

The sequencing was later done by the rest of the group members. It was observed that they discussed the storyline and collaborated actively in the lesson. Most of them showed their understanding as they were able to rephrase the story into their mother tongue. S3 and S6 were able to recall the story well as indicated in the extracts below when they mentioned about the cat and the evil servants. 
$<$ Okay, this one is number 3 about the cat that caught all the rats. $>$ (S3, post) $<$ I remember the fifth one... It is about the evil servants. $>$ (S4, post)

In a nutshell, the students' understanding towards the listening text improved significantly when the YouTube and video podcast were used in the lesson. Furthermore, the presence of audio-visual and subtitles helped them to comprehend the listening text better as compared to the pre-observation whereby the tendency of guessing was higher than trying to understand the story based on the context.

\section{Discussion}

This study examined the impact of YouTube and Video Podcast on listening comprehension of the Primary Year 4 students. The data were obtained using both quantitative and qualitative in an action research project which was conducted for 8 weeks. The findings of this study revealed that there was a statistically significant impact of the YouTube and video podcast on the students' listening comprehension. The listening scores improved significantly after the intervention. The findings were also supported by the classroom observation whereby students were seen to be more involved in their learning. They showed their understanding of the story as they were able to describe the characters and the plot clearly through discussion with their peers. In addition, four themes emerged from the observation which indicated that the YouTube and video podcast not only increased the students' participation and understanding, but also increased their collaboration and team spirit. Undoubtedly, it has also reduced their listening anxiety and increased their interest and motivation to listen to the English texts.

In a nutshell, the findings of this study are in accordance with the past studies on the positive impacts of YouTube and Video-Podcast on listening comprehension [50]; [51]; [52]; [53]; [54]. These studies disclosed that the use of technology such as YouTube and Video-Podcast has impacted the listening comprehension of the pupils regardless of age and background. This is due to the fact that YouTube and video-Podcast have fun elements that can help students to be more focused on the lesson. In a similar vein, [55] conducted a study comparing the traditional teaching of using audio-based learning on listening comprehension skills with the application of technology. These studies revealed that not only YouTube and Video-Podcast are suitable teaching tools to teach listening comprehension but they are also able to retain the students' attention towards the listening text. Besides, they are interesting, engaging, and more effective compared to the traditional audio-based language teaching. The theory of Social Constructivism has supported the findings of the study that students learn and understand better when they work in groups. It is suggested that language develops from social interaction and ultimately, plays an important role in cognitive development [46].

The findings also revealed that their team spirit increased when different gender groups were competing with each other to solve the listening task. They became more competitive when trying to solve the listening comprehension. Students were easily attracted to the multimedia elements and that they actively filtered, selected, organized and integrated information they received with the help of multimedia. 


\section{Conclusion}

In conclusion, the use of YouTube and Video-Podcast is seen to be an effective teaching tool for enhancing listening comprehension among younger learners with limited English proficiency. However, technology alone is not enough. Teachers play an important role in making the listening lesson more effective for ESL learners. Teachers need to act as the facilitator of students' learning so that they can become a role model in using technology for educational purposes. They can assist pupils who have difficulties in uploading their learning materials in the channel [56] and they can also write constructive feedback to the pupils in the YouTube. The constructive feedback given by the teachers and other viewers can become the center of developing creativity and improvements among the pupils towards the learning [39]. In light of the teachers' role in the 21 st century teaching and learning, teachers need to equip themselves with the technological skills and tools. Teachers also need to establish networking with other teachers from all over the world. This is because the YouTube, which is a globalized website enables collaboration with one another whereby more inputs can be gained globally from other teachers. [57] identified barriers such as teachers' knowledge of ICT, funding for ICT, traditional teaching style, professional development, as well as district and school culture. The collaboration of teachers from all around the world can help to develop more authentic learning materials in the YouTube and improve the listening comprehension performance which is the most important skill in language learning. Teachers and parents also need to monitor students' online activities as they impact the psychological well being of the students [58]. Even though this study was conducted in a school in an ESL context, the methods used in this action research project can be applied to any ESL contexts in any parts of the world.

\section{$7 \quad$ Acknowledgements}

The writers would like to thank the Research Management Centre, International Islamic University Malaysia, for the grant, P-RIGS18-025-0025, that made the publication of this work possible.

\section{References}

[1] Butt, M. N., Sharif, M. M., Naseer-ud-Din, Hussein, I., Khan, F. Ayesha, U. "Listening Comprehension Problems among the Students: A Case Study of Three Govt. Boys' Higher Secondary Schools," European Journal of Social Sciences, vol. 18, no. 2, pp. 311-315, 2010.

[2] Walker, N. "Listening: The most difficult skill to teach," Encuentro, vol. 23, no. 1, pp. 167-175, 2014.

[3] Golchi, M. M. "Listening Anxiety and Its Relationship with Listening Strategy Use and Listening Comprehension among Iranian IELTS Learners," International Journal of English Linguistics, vol. 2, no. 4, pp. 115-128, 2012. Retrieved from: http://citeseerx.ist.psu.edu. https://doi.org/10.5539/ijel.v2n4p115 
[4] Kimura, H. "A Self-Presentational Perspective On Foreign Language Listening Anxiety," Unpublished Doctor of Education Dissertation, Temple University, USA, 2011. Retrieved from: http://gradworks.umi.com/34/77/3477769.html

[5] Buck, G. Assessing Listening, New York: CAP, 2001. https://doi.org/10.1017/ CBO9780511732959

[6] Bloomfield, A., Wayland, S., Rhoades, E., Blodgett, A., Linck, J., Ross, S. "What Makes Listening Difficult? Factors Affecting Listening Comprehension," University of Maryland CASL, pp. 1-79, 2010. https://doi.org/10.21236/ADA550176

[7] Alwehaibi, H. O. "The Impact of Using YouTube in EFL Classroom on Enhancing EFL Students' Content Learning," The Clute Institute International Academic Conference, pp. 935-940, 2013.

[8] Abbas, J., Aman, J., Nurunnabi, M., Bano, S. "The Impact of Social Media on Learning Behaviour for Sustainable Education: Evidence of Students from Selected Universities in Pakistan," Sustainability, vol. 11, no. 6, pp. 1-23, 2019. https://doi.org/10.3390/su11061683

[9] Raut, V. and Patil, P. "Use of Social Media in Education: Positive and Negative Impact on the Students," International Journal on Recent and Innovation Trends in Computing and Communication, vol. 4, no. 1, pp. 281-285, 2016.

[10] Mensah, S. O., Nizam, D. I., Mensah, O. S. "The Impact of Social Media on Students' Academic Performance," International Journal of Education, Learning and Training, vol. 1, no. 1, pp. 14-21, 2016. https://doi.org/10.24924/ijelt/2016.11/v1.iss1/14.21

[11] Kim, J. "The Institutionalization of YouTube: From User-Generated Content to Professionally Generated Content," Media, Culture \& Society, vol. 34, no. 1, pp. 53-67, 2012. https://doi.org/10.1177/0163443711427199

[12] Chhabra, P. "Use of E-Learning Tools in Teaching English," International Journal of Computing \& Business Research, vol. 3, pp. 2229-6166, 2012.

[13] Brunner, I. "Using Language Learning Resources on YouTube," ICT for Language Learning, pp. 1-5, 2013.

[14] Buzzetto-More, N. A. "An Examination of Undergraduate Students' Perceptions And Predilections of the Use of Youtube in the Teaching and Learning Process," Interdisciplinary Journal of E-Learning and Learning Objects, vol. 10, pp. 17-32, 2014. http://www.ijello.org/ Volume10/IJELLOv10p017032Buzzetto0437.pdf

[15] Alimemaj, Z. "YouTube, Language Learning and Teaching Techniques," The Magazine of Global English Speaking Higher Education, vol. 2, no. 3, pp. 10-12, 2012.

[16] McKinney, A., Page, K. "Podcasts and Video Streaming: Useful Tools to Facilitate Learning of Pathophysiology in Under Graduate Nurse Education?" Nurse Education in Practice, vol. 9, no. 6, pp. 372-376, 2009. https://doi.org/10.1016/j.nepr.2008.11.003

[17] Rahimi, M., Katal, M. "The Role of Metacognitive Listening Strategies Awareness and Podcast-Use Readiness in Using Podcasting for Learning English as a Foreign Language," Computer in Human Behaviour, vol. 28, pp. 1153-1161, 2012. https://doi.org/10.1016/j. chb.2012.01.025

[18] Cross, J. "Promoting Autonomous Listening to Podcasts: A Case Study," Language Teaching Research, vol. 18, no. 1, pp. 8-32, 2014. https://doi.org/10.1177/1362168813505394

[19] Alm, A. "Extensive Listening 2.0 With Foreign Language Podcasts," Innovation in Language Learning and Teaching, vol. 7, no. 3, pp. 266-280, 2013. https://doi.org/10.1080/175 01229.2013 .836207

[20] Akbari, O., Razavi, A. "Using Authentic Materials in The Foreign Language Classrooms: Teachers' Perspectives in EFL Classes," International Journal of Research Studies in Education, vol. 4, no. 5, 2015. https://doi.org/10.5861/ijise.2015.1189 
[21] Sailin, S. N., Maamor, N. A. “Improving Student Teachers' Digital Pedagogy Through Meaningful Learning Activities," Malaysian Journal of Learning and Instruction, vol. 15, no. 2, pp. 143-173, 2018. https://doi.org/10.32890/mjli2018.15.2.6

[22] Mohammad Nidzam Yaakob, Ahmad Sobri Shuib, Nurahimah Mohd Yusoff, Shamshul Bahar Yaakob. "Pembangunan Model M-Pembelajaran untuk Kursus Teknologi Dalam pengajaran dan Pembelajaran IPG: Satu Analisis Keperluan", Practitioner Research, vol. 1, pp. 87-110, 2019.

[23] Hamouda, A. "An Investigation of Listening Comprehension Problems Encountered by Saudi Students in the EL Listening Classroom," International Journal of Academic Research in Progressive Education and Development, vol. 2, no. 2, pp. 113-155, 2013.

[24] Nadig, A. (2013). "Listening Comprehension," Encyclopaedia of Autism Spectrum Disorders, Springer, 2013.

[25] Dirven, R., Oakeshott-Taylor, J. "Listening Comprehension (Part I)," Language Teaching: The International Abstracting Journal for Language Teachers and Applied Linguistics, vol. 17, no. 4, pp. 326-343, 1984. https://doi.org/10.1017/S026144480001082X

[26] Hasan, A. "Learners' Perceptions of Listening Comprehension Problems. Language”, Culture and Curriculum, vol. 13, no.2, pp. 137-152, 2000. Retrieved October11, from EBSCOhost database. https://doi.org/10.1080/07908310008666595

[27] Herreid, C. F., \& Schiller, N. "Case Studies and the Flipped Classroom," Journal of College Science Teaching, vol. 42, no. 5, pp. 62-66, 2013.

[28] Seferoglu, G., \& Uzakgoren, S. "Equipping Learners with Listening Strategies in English Language Classes," Hacettepe University Journal of Education, vol. 27, pp. 223-231, 2004.

[29] Nation, I. S. P., \& Newton, J. Teaching ESL/EFL Listening and Speaking. New York: Routledge, 2009. https://doi.org/10.4324/9780203891704

[30] Budiaman, B., Komarudin, K., Nuruddin, N. and Kustandi, C. "Learning Design on Social Studies Through Digital Books in Senior High School”, i-jim, vol. 15, no. 9, pp. 154-166, 2021. https://doi.org/10.3991/ijim.v15i09.18435

[31] Eldokhny, A. A. and Drwish, A. M. "Effectiveness of Augmented Reality in Online Distance Learning at the time of the COVID-19 Pandemic", i-JET, vol. 16, no. 9, pp. 198-218, 2021. https://doi.org/10.3991/ijet.v16i09.17895

[32] Jaffar, A. A. "YouTube: An Emerging Tool in Anatomy Education", Anatomical Sciences Education, vol. 5, no. 3, pp. 158-164, 2012. https://doi.org/10.1002/ase.1268

[33] Nycyk, M. "Tensions in Enforcing YouTube Community Guidelines: The Challenge of Regulating User's Flaming Comments,". Unpublished doctoral dissertation, Curtin University of Technology, 2012.

[34] Oddone, C. (2011). "Using Videos from YouTube and Websites in the CLIL Classroom," Studies about Languages, vol. 18, no. 18, pp. 105-110, 2011. https://doi.org/10.5755/j01. $\underline{\text { sal.0.18.417 }}$

[35] Callow, J., \& Zammit, K. “Where lies your text?' (Twelfth Night Act I, Scene V): Engaging High School Students from Low Socioeconomic Backgrounds Reading Multimodal Texts," English in Australia, vol. 47, no. 2, pp. 69-77, 2012.

[36] Duffy, P. "Engaging then YouTube Google-eyed generation: Strategies for using Web 2.0 in teaching and learning," The Electronic Journal of e-Learning, vol. 6, no. 2, pp. 119-130, 2008. Retrieved from: http://www.ejel.org/volume6/issue2

[37] Romrell, D., Kidder, L. C., \& Wood, E. "The SAMR Model as a Framework for Evaluating mLearning," Online Learning: Official Journal of the Online Learning Consortium, vol. 18, no. 2, pp. 1-15, 2014. https://doi.org/10.24059/olj.v18i2.435

[38] Crane, R. \& Kuyken, W. "The Implementation of Mindfulness-Based Cognitive Therapy: Learning from the UK Health Service Experience”, Mindfulness, vol. 4, pp. 246-254, 2012. https://doi.org/10.1007/s12671-012-0121-6 
[39] Langer de Ramirez, L. Empower English Language Learners with Tools from the Web, 2010. Thousand Oaks, Sage.

[40] Terhune, N. M. "Language Learning Going Global: Linking Teachers and Learners Via Commercial Skype-Based CMC. Computer Assisted Language Learning”, vol. 29, no. 6, pp. 1071-1089, 2016. https://doi.org/10.1080/09588221.2015.1061020

[41] Basaran, S., \& Cabaroglu, N. "Language Learning Podcasts and Learners' Belief Change", TESL-EJ, vol. 17, no. 4, pp. 1-32, 2014.

[42] Rahman, A., Atmowardoyo, H., Salija, K. "Podcast Effects on EFL Learners' Listening Comprehension", ELT Worldwide. Journal of English Language Teaching, vol. 5, no. 2, pp. 151-164, 2018. https://doi.org/10.26858/eltww.v5i2.7374

[43] Zamari, Z., Adnan, A. H, Idris, S. L., \& Yusof, J. "Students' Perceptions of Using Online Language Learning Materials,” Procedia-Social and Behaviour Sciences, vol. 67, pp. 611-620, 2011. https://doi.org/10.1016/j.sbspro.2012.11.367

[44] Morrissey, J. "Podcast Steering of Independent Learning in Higher Education," AISHE-J, vol. 4, no. 1, pp. 1-12, 2012.

[45] Chan, W. M., Chen, I. R., \& Dopel, M. "Podcasting in Foreign Language Learning: Insights for Podcast Design From A Developmental Research Project," In M. Levy, F. Blin, C. Bradin Siskin \& O. Takeuchi (Eds.), Worldcall: Global Perspectives on Computer Assisted Language Learning, London, Routledge, pp. 19-37, 2011.

[46] Vygotsky, L. S. Mind in Society: The Development of Higher Psychological Processes, Cambridge, HUP, 1978.

[47] Braun, V., and Clarke, V. Successful Qualitative Research: A Practical Guide for Beginners. London: Sage Publications Ltd, 2013.

[48] Song, W. "Listening Comprehension Strategies Used by EFL Postgraduate Students", Unpublished master's thesis, University of Malaya, Kuala Lumpur, Malaysia, 2016.

[49] Martinez, R. G. "Effects on Teaching Listening Skills through Videos to Advanced Students from the Foreign Language Department at the University of El Salvador During First Semester 2010," Unpublished Master's Thesis, University of El Salvador, El Salvador, 2016.

[50] Abdalhamid, F. "Listening Comprehension Strategies of Arabic- Speaking ESL Learners," Master's Dissertation, Department of English, Colorado State University, Fort Collins, Colorado, 2012.

[51] Nomass, B. B. "The Impact of Using Technology in Teaching English as a Second Language," English Language and Literature Studies, vol. 3, no. 1, pp. 111-116, 2013. https://doi.org/10.5539/ells.v3n1p111

[52] Al-Alwan, A., Asassfeh, S., \& Al-Shboul, Y. "EFL Learners' Listening Comprehension and Awareness of Metacognitive Strategies: How Are They Related?" International Education Studies, vol. 6, no. 9, pp. 31-39, 2013. https://doi.org/10.5539/ies.v6n9p31

[53] Yesilyurt, E. “An Analysis of Teacher Candidates' Usage Level of Meta-Cognitive Learning Strategies: Sample of a University in Turkey," Educational Research and Reviews, vol. 8, no. 6, pp. 218-225, 2013.

[54] Azmi, B. M., Celik, B., Yidliz, N., \& Tugrul, M. C. Listening Comprehension Difficulties Encountered by Students in Second Language Learning Class. Journal of Educational and Instructional Studies in the World, vol. 4, no. 4, pp. 1-6, 2014.

[55] Abidin, M. J. Z., Mohammadi, M. P., Souriyavongsa, T., Bun Tiang, C. D., Ong Liew Kim, N. "Improving Listening Comprehension among Malay Preschool Children Using Digital Stories," International Journal of Humanities and Social Science, vol. 1, no. 14, pp. 159-164, 2011.

[56] Polyudova, E. Acquiring Lingua Franca of the Modern Time: Current Issues and Strategies in ESL Studies, Newcastle Upon Tyne, Cambridge Scholars Publishing, 2014. 
[57] Prasojo, L. D., Habibi, A., Yaakob, M. F. M., Mukminin, A., Haswindy, S., Sofwan, M. "An Explanatory Sequential Study on Indonesian Principals' Perceptions on ICT Integration Barriers," Electronic Journal of e-Learning, vol. 17, no. 1, pp. 1-10, 2019.

[58] Tantari, E. and Lutaj, L. "The Impact of Social Network Sites on Students' Psychological Problems" i-JET, vol. 16, no. 9, pp. 108-118, 2021. https://doi.org/10.3991/ijet. $\underline{\mathrm{v} 16 \mathrm{i} 09.20799}$

\section{Authors}

Dr. Aizan Yaacob is an Associate Professor at the School of Education, Universiti Utara Malaysia. She obtained her PhD in English Language Teaching (ELT) and Applied Linguistics from the University of Warwick, United Kingdom. Her areas of specialization include ELT, Applied Linguistics, Bilingualism, Teaching English to Young Learners, and qualitative research. She is the editor-in-chief of Practitioner Research. Email: aizan904@uum.edu.my

Amira Shazmin Amir Binti Amir has been teaching English for 4 years at SK Putra, Kangar, Perlis, Malaysia. She obtained her Master in Education (ELT) from Universiti Utara Malaysia. Her research interests include Teaching English to Young leaners, Web 2.0 tools for teaching English and distance learning. Email: myramalaussieip6@gmail.com

Dr. Ratnawati Mohd. Asraf is a professor at the Kulliyyah of Education, and Director of the Research Management Centre, International Islamic University Malaysia. She obtained her Ph.D. from Florida State University, USA, and has published numerous articles in the field of education, critical thinking, reading, literacy, TESL or TEFL, and the use of statistics in social and behavioral science research. She was formerly the editor of Educational Awakening: Journal of the Educational Sciences, a refereed journal published by the International Islamic University Malaysia Press. Email: ratnawati@iium.edu.my

Dr. Mohd Faiz Mohd Yaakob is a Senior Lecturer at the School of Education, College of Arts and Sciences, Universiti Utara Malaysia. He has more than 10 years of teaching experience in school. His expert and research interests are Educational Planning and Policy, Educational Administration and Islamic Studies. Email: mohdfaizmohdyaakob@gmail.com

Dr. Farah Mohamad Zain is a Senior Lecturer in Educational Technology. She is currently the Coordinator of Postgraduate programmes at the School of Education, College of Arts and Sciences, Universiti Utara Malaysia. Dr. Farah hold a PhD from Universiti Sains Malaysia and has 8 years of teaching experience. Her research areas include digital content development, instructional technology, scholarship of teaching and learning and augmented reality. Email: mz.farah@uum.edu.my

Article submitted 2021-05-03. Resubmitted 2021-06-15. Final acceptance 2021-06-21. Final version published as submitted by the authors. 